Vol. 4 No. 3 September 2017

\title{
AKIBAT HUKUM AKTA OTENTIK YANG TERDEGRADASI MENJADI AKTA DIBAWAH TANGAN
}

\author{
Soegeng Ari Soebagyo*, Gunarto** \\ * Mahasiswa Program Magister (S2) Kenotariatan Fakultas Hukum UNISSULA, Semarang, e-mail: \\ soegengari123@gmail.com \\ ** Dosen Fakultas Hukum UNISSULA, Semarang
}

\begin{abstract}
The study entitled "Legal Effects Against the Authentic Deed of Degradation Becoming a Deed of Hands" aims to recognize the legal consequences of the degraded authentic deed and the responsibility of Notary over the degraded authentic deed to become a deed under the hand. This research uses juridical socio legal research approach, in collecting data more emphasized on source of primary material, in the form of legislation, studying law norms and law science sera theory in addition to interviews to the parties related to the problem in carefully. Based on the method, the research produces principally (i) Authentic deeds can be degraded into deeds under the hand when the requirements of the authentic deed are not met, whether material or formal terms which have the authority to judge them is a court. ) What are the legal consequences of an authentic deed that is deemed to be a deed under the hand does not have legal validity as an authentic deed, only a word under the hand that has no legal force to bind this subject under KUHperdata article 1869 and can be seen in Law no. 2 Year 2014 jo. UU no. (3) Article 51 paragraph (4), (iii) The responsibility of a Notary if The authentic deed he made into a deed under the hand, the Notary may be held accountable; (-) Administrative liability If a Notary is found guilty of violating Article 85 of Law Number 30 Year 2004 which regulates the obligation and prohibition for Notary in carrying out his / her position. (-) Accountability according to Civil Law of this matter as Article 1365 Civil Code, and can be seen In Law no. 2 Year 2014 jo. UU no. Article 49 paragraph (3) of Article 49 paragraph (4), Article 50 paragraph (5), Article 51 paragraph (4) (-) Accountability under criminal law if Notary deliberately falsely authentic deed or intentionally include incorrect information in the authentic deed he made
\end{abstract}

Keywords: Authentic Deed, Notary, Degradation

\section{PENDAHULUAN}

Setiap orang yang mendalilkan bahwa ia mempunyai suatu hak, atau guna meneguhkan haknya sendiri maupun membantah suatu hak orang lain menunjuk pada suatu peristiwa,diwajibkan membuktikan adanya hak atau peristiwa tersebut sebagaimana dimaksud pada Pasal 1865 KUHPerdata $^{1}$. dalam pasal tersebut menghendaki bahwa seseorang yang mendalilkan mempunyai hak,atau membantah hak

1 R.Subekti dan R.Tjitrosudibio, 1995, Kitab Undang-undang Hukum Perdata cet.27..Pradnya Paramita,Jakarta, hlm. 475. milik orang lain, harus dapat membuktikannya berdasarkan alat bukti yang diatur dalam peraturan perundang-undangan berlaku.

Hal ini untuk menjamin kepastian, ketertiban dan perlindungan hukum atas hak-hak pribadi seseorang maka diaturlah hak-hak tersebut kedalam peraturan hukum Perdata atau hukum privat sebagai hukum sebagai hukum materiil yang mana hukum Acara Perdata sebagai hukum formilnya.

Salah satu fungsi Hukum Acara Perdata adalah peraturan hukum yang mengatur bagaimana cara menjamin ditaatinya hukum perdata materiil, dengan perantara hakim, Hukum 
Acara mengatur bagaimana cara seseorang mengajukan tuntutan hak,memeriksa serta memutusnya dan melaksanakan putusannya, hal ini untuk mencegah main hakim sendiri atau eigenrechting. ${ }^{2}$

Dalam mengajukan tuntutan hak seseorang harus cukup bukti agar tuntutannya tidak sia-sia, dalam Hukum Acara Perdata dikenal beberapa alat bukti sebagaimana diatur dalam Pasal 1867 KUHPerdata, yaitu : Bukti dengan Saksi-saksi, Persangkaan-persangkaan, Pengakuan dan Sumpah. Dalam Pembuktian dengan tulisan dilakukan dengan akta otentik maupun dengan akta dibawah tangan, akta adalah suatu tulisan yang sengaja dibuat untuk dapat dijadikan bukti bila ada suatu peristiwa dan ditanda tangani. ${ }^{3}$

Akta Otentik adalah akta yang dibuat dihadapan pejabat (Notaris) sedangkan akta dibawah tangan adalah kesepakatan para pihak yang melakukan perjanjian. Akta mempunyai 2 (dua) fungsi penting yaitu : Fungsi formil ( formalitas causa) dan fungsi alat bukti ( probotionis causa).

Pejabat yang berwenang membuat akta otentik adalah Notaris hal ini sebagaimana sebagai di atur dalam Pasal 1 angka 1,Undang-undang Nomor 2 Tahun 2014 dan staatsblad 1860-3. Yang mana pengertian Notaris yaitu sebagai berikut Notaris adalah Pejabat umum yang satu-satunya berwenang untuk membuat akta otentik mengenai semua perbuatan, perjanjian dan ketetapan yang diharuskan oleh suatu peraturan umum atau dikehendaki oleh yang berkepentingan agar dinyatakan dalam suatu akta otentik, menjamin kepastian tanggalnya,menyimpan aktanya dan daripada itu memberikan gross,salinan dan kutipannya kesemua itu sebegitu jauh pembuatan akta itu oleh suatu peraturan umum tidak boleh ditugaskan atau dikecualikan kepada pejabat atau orang lain. ${ }^{4}$

Menurut Pasal 15 Undang-undang No.2 Tahun 2014 jo. Undang-undang No.30 Tahun 2004

2 Sudikno Mertokusumo,2006,Hukum Acara perdata Indonesia, Liberty , Yogyakarta,hlm. 15.

${ }^{3}$ R.Subekti,2001,Hukum Pembuktian,Pradinya Paramita Jakarta, hlm.48.

${ }^{4}$ Komar Andasasmita, 1983, Notaris Selayang Pandang, Cet.kedua,Alumni, Bandung, hlm.2. kewenangan Notaris, sebagai berikut : (1) Notaris berwenang membuat akta autentik mengenai semua perbuatan, perjanjian,dan penetapan yang harus dilaksanakan oleh peraturan perundangundangan dan/atau yang dikehendaki oleh yang berkepentingan untuk dinyatakan dalam Akta autentik,menjamin kepastian tanggal pembuatan Akta,menyimpan Akta,memberikan grosse,salinan dan kutipan Akta,semuanya itu sepanjang pembuatan Akta itu tidak juga ditugaskan atau dikecualikan kepada pejabat lain atau orang lain yang ditetapkan oleh undang-undang. (2) Mengesahkan tanda tangan dan menetapkan kepastian tanggal surat dibawah tangan dengan mendaftar dalam buku khusus, membukukan surat dibawah tangan dengan mendaftar dalam buku khusus, membuat kopi dari asli surat dibawah tangan berupa salinan yang memuat uraian sebagaimana ditulis dan digandakan dalam surat yang bersangkutan, Melakukan pengesahan kecocokan fotokopi dengan surat aslinya, Memberikan penyuluhan hukum sehubungan dengan pembuatan akta,Membuat Akta yang berkaitan dengan pertanahan., atau Membuat Akta risalah lelang

Bahwa akta sebagaimana akta yang mempunyai kekuatan pembuktian adalah Akta Notaris, yaitu akta otentik yang memiliki kekuatan hukum dengan jaminan kepastian hukum sebagai alat bukti tulisan yang sempurna (volledig bewijs ),tidak memerlukan tambahan alat pembuktian lain dan hakim terikat karenanya. ${ }^{5}$

Akta yang dibuat Notaris memiliki kekuatan pembuktian yang sempurna tidak seperti akta dibawah tangan.akta dibawah tangan adalah akta yang dibuat sendiri oleh pihak-pihak yang berkepentingan tanpa bantuan pejabat umum ${ }^{6}$. Akta notaris sebagaimana di maksud adalah akta yang di buat oleh notaris yang mempunyai kekuatan hukum mengikat dalm sebuah perjanjian atau perikatan yang dilakukan oleh masyarakat, yang mana secara fungsi di gunakan untuk

5 A.A.Andi Prajidno,2010,Apa dan Siapa Notaris di Indonesia ?, Cet. Pertama,Putra Media Nusantara,Surabaya,hlm.51.

6 Taufik Makarao,2004,Pokok-Pokok Hukum Acara Perdata, Rinaka Cipta, Jakarta,hlm.100. 
pembuktian di kemudian hari apabila ada persoalan antara kedua belah pihak.

Akta otentik yang merupakan bukti yang lengkap (mengikat)berarti kebenaran dari hal-hal yang tertulis dalam akta tersebut dianggap sebagai benar,selama kebenarannya itu tidak ada pihak lain yang dapat membuktikan sebaliknya ${ }^{7}$.

Akta Notaris lahir karena adanya keterlibatan langsung dari pihak yang menghadap Notaris, para pihak yang menjadi pemeran utama dalam pembuatan sebuah akta sehingga tercipta sebuah akta otentik. Akta Notaris adalah Akta otentik yang dibuat oleh atau dihadapan Notaris menurut bentuk dan tatacara yang ditetapkan dalam undang-undang.Akta yang dibuat Notaris menguraikan secara otentik mengenai semua perbuatan,perjanjian dan penetapan yang disaksikan oleh para penghadap dan saksi-saksi ${ }^{8}$.

Walaupun akta Notaris merupakan alat bukti yang sempurna, sebagaimana dimaksud dalam Pasal 1870 KUH Perdata,namun akta Notaris dalam praktik dapat mengalami degradasi kekuatan alat bukti.degradasi akta Notaris diartikan sebagai akta Notaris yang tidak dapat diperlakukan sebagai akta otentik namun dianggap sebagai tulisan dibawah tangan, hal ini terjadi bila Notaris dalam membuat suatu Akta tidak memenuhi semua ketentuan dalam UU.Jabatan Notaris dan Peraturan Perundang-undangan lainnya.

Berdasarkan latar belakang tersebut diatas maka penulis tertarik untuk melakukan penelitian dan membahasnya lebih jauh kedalam jurnal yang berjudul " Akibat Hukum Akta Otentik Yang Terdegradasi Menjadi Akta Dibawah Tangan".

\section{METODE PENELITIAN.}

Penelitian hukum merupakan suatu kegiatan ilmiah yang didasarkan pada metode, sistematika, dan pemikiran tertentu yang bertujuan untuk mempelajari salah satu atau beberapa gejala hukum tertentu dengan jalan menganalisanya.

7 Teguh Samudra,2004,Hukum Pembuktian dalam Acara Perdata, edisi pertama, Alumni, Bandung, hlm. 49.

8 Wawan Tunggal Alam,2001,Hukum Bicara Kasus-kasus dalam Kehidupan Sehari-hari,Milenia Populer, Jakarta, hlm.85.
Kecuali itu maka juga diadakan pemeriksaan yang mendalam terhadap fakta hukum tersebut untuk kemudian megusahakan suatu pemecahan atas permasalahan-permasalahan yang timbul dalam gejala yang bersangkutan. Usaha-usaha tersebut dapat dilakukan dengan menggunakan berbagai macam metode ilmiah. adapun metode yang digunakan untuk mencapai usaha tersebut adalah metode penelitian. dengan menggunakan metode penelitian ini diharapkan akan membawa hasilhasil yang dapat dipertanggungjawabkan kebenarannya karena dari penelitian ini dapat mengungkapkan kebenaran secara sistematis, metodologis dan konsisten.

Metode pendekatan yang digunakan dalam penelitian ini adalah pendekatan yuridis sosio legal research, yaitu metode penelitian yang mendekati suatu permasalahan melalui penggabungan antara analisa normatif dengan pendekatan ilmu nonhukum/faktor-faktor sosial dalam melihat hukum dan kemudian dihubungkan dengan kenyataan yang ada mengenai akibat hukum akta otentik yang terdegradasi menjadi akta di bawah tangan.

\section{HASIL PENELITIAN DAN PEMBAHASAN}

Akta otentik dapat terdegradasi menjadi akta di bawah tangan ketika syarat-syarat dalam akta otentik tersebut tidak terpenuhi, baik syarat materiil ataupun syarat formilnya. Pengujian apakah akta otentik tersebut memenuhi syaratsyarat tersebut menjadi kewenangan pengadilan untuk memeriksa. Pengadilan dalam memeriksa untuk membatalkan suatu akta tergantung permintaan pihak yang mengajukan gugatan atau permohonan, karena pembatalan suatu akta adalah bagian dari hukum perdata sehingga pengadilan pada prinsipnya sifatnya pasif, hanya memeriksa serta mengadili apa yang di ajukan oleh penggugat. 9

Pengadilan dalam membatalkan akta otentik mendasarkan pada undang-undang yang berlaku, apakah akta otentik di buat itu melanggar ketentuan perundangan atau tidak, melawan

9 Wawancara dengan AGUS GIHARNO, SHLM. Panitera Muda Perdata Pengadilan Negeri Pekalongan pada tanggal 4 Agustus 2017 
hukum atau tidak.10 Pengadilan berwenang membatalkan akta otentik yang di buat oleh Notaris yang mana alasan-alasan yuridis secara umum pembatalan akta Notaris yang pada umumnya sama dengan alasan-alasan yuridis batalnya perjanjian.

Akta Notaris yang dapat dibatalkan karena dari sudut yang menghadap tidak memenuhi syarat subjektif sahnya perjanjian sebagaimana tersebut dalam Pasal 1320 KUHPerdata, yaitu :

1. Kesepakatan mereka yang mengikatkan dirinya; (KUHPerd. 28, 1312 dst.)

2. Kecakapan untuk membuat suatu perikatan; (KUHPerd. 1329 dst.) 11

Sedangkan akta Akta Notaris yang batal demi hukum karena syarat materil tidak dipenuhi atau tidak memenuhi syarat objektif sahnya perjanjian sebagaimana tersebut dalam Pasal 1320 KUHPerdata, yaitu :

1. Suatu pokok persoalan tertentu; (KUHPerd. 1332 dst.)

2. suatu sebab yang tidak terlarang. (KUHPerd. 1335 dst.) 12

Akta otentik yang di batalkan pengadilan akta Notaris terdegradasi nilai pembuktiannya sebagaimana akta dibawah tangan telah ditentukan dalam Pasal 1868 dan 1869 KUHPerdata dan ditentukan oleh UUJN sendiri, yaitu :

Pasal 1868 : suatu akta otentik ialah suatu akta yang dibuat dalam bentuk yang ditentukan undang-undang oleh atau di hadapan pejabat umum yang berwenang untuk itu di tempat akta itu dibuat. Dan pasal 1869 : suatu akta yang tidak dapat diperlakukan sebagai akta otentik, baik karena tidak berwenangnya atau tidak cakapnya pejabat umum yang bersangkutan maupun karena cacat dalam bentuknya, mempunyai kekuatan sebagai tulisan i bawah tangan bila ditandatangani oleh para pihak.

Berdasarkan Pasal 1869 KUHPerdata bahwa akta Notaris akan mempunyai kekuatan pembuktian sebagai tulisan dibawah tangan jika :

10 Ibid

11 Wawancara dengan LAILA, SHLM.S.Pn. Notaris Pekalongan pada tanggal 4 Agustus 2017

12 Ibid.
1. Tidak berwenangnya pejabat umum yang bersangkutan.

2. Tidak cakapnyanya (tidak mampunya) pejabat umum yang bersangkutan.

3. Cacat dalam bentuknya.

Sanksi Hukum Administrasi terhadap Notaris karena kesalahannya yang membuat akta otentik menurut Pasal 85 UUJN menyangkut ketentuan sebagaimana dimaksudkan dalam Pasal 7, Pasal 15 ayat (1,2 dan 3 ), Pasal 16 ayat (1) huruf a, Pasal 16 ayat (1) huruf b Pasal 16 ayat (1) huruf c, Pasal 16 ayat (1) huruf d, Pasal 16 ayat (1) huruf e, Pasal 16 ayat (1) huruf $f$, Pasal 16 ayat (1) huruf g, Pasal 16 ayat (1) huruf h, Pasal 16 ayat (1) huruf I, Pasal 16 ayat (1) huruf j, Pasal 16 ayat (1) huruf k, Pasal 17, Pasal 20, Pasal 27, Pasal 32, Pasal 37, Pasal 54, Pasal 58, dan/atau Pasal 63, dapat dikenai sanksi berupa:

a. Teguran lisan;

b. Teguran tertulis;

c. Pemberhentian sementara;

d. Pemberhentian dengan hormat: atau

e. Pemberhentian dengan tidak hormat.

Majelis Pengawas Daerah (MPD) tidak punya kewenangan untuk menjatuhkan Sanksi Administratif. Pelangggaran UUJN/UUJN-P oleh Notaris telah ada sanksi tersendiri untuk Notaris sebagaimana tersebut di atas, dengan demikian secara normatif tidak ada sanksi lain selain yang tersebut di atas. Pelanggaran UUJN/UUJN-P bukan merupakan tindak pidana, karena terhadap pelanggaran tersebut UUJN/UUJN-P telah mengatur sanksinya dan tidak mengatur ketentuan pidana. Dengan Catatan Dalam Undangundang Republik Indonesia Nomor 12 Tahun 2011 disebutkan dalam Lampiran I C3. bahwa ketentuan pidana akan ada/disebutkan dalam undangundang yang bersangkutan jika diperlukan.

Seperti halnya proses penjatuhan saksi maka di butuhkan pembuktian atas tuntutan yang di tuduhkan kepada Notaris yang mana dalam penjatuhan saksi andmistrasi yang berwenang memerisa dan mengadili adalah majelis kode etik sedangkan sanksi pidana atau sanksi perdata yang memeriksa dan mengadili adalah pengadilan.

Tanggung jawab Notaris bila dilihat dari Undang-Undang Nomor 30 Tahun 2004 jo. Undang-Undang Republik Indonesia Nomor 2 
Tahun 2014 adalah sangat erat kaitannya dengan tugas dan pekerjaan Notaris dengan akta otentik. Pasal 1 ayat 1 UUJN dan Pasal 15 UUJN telah menegaskan, bahwa pada pokoknya tugas pokok dari Notaris adalah membuat akta otentik dan akta otentik itu akan memberikan kepada pihak-pihak yang membuatnya suatu pembuktian yang sempurna. Hal ini dapat dilihat sebagaimana yang tercantum dalam Pasal 1870 KUHPerdata yang menyatakan bahwa suatu akta otentik memberikan di antara para pihak beserta ahli waris-ahli warisnya atau orang-orang yang mendapat hak daripada mereka, suatu bukti yang sempurna tentang apa yang dimuat di dalamnya. Disinilah letaknya arti yang penting dari profesi Notaris ialah bahwa ia karena undang-undang diberi wewenang menciptakan alat pembuktian yang sempurna, dalam pengertian bahwa apa yang tersebut dalam otentik itu pada pokoknya dianggap benar.13 Sehingga dalam pasal Pasal 16 ayat (1) huruf a UUJN, bertindak amanah, jujur, saksama, mandiri, tidak berpihak, dan menjaga kepentingan pihak

Pertanggungjawaban Notaris sebagai pejabat umum meliputi bidang: hukum privat, hukum pajak, dan hukum pidana. Ada kemungkinan bahwa pertanggungjawaban disatu bidang hukum tidak menyangkut bidang hukum yang lain. Sebaliknya, tindakan yang menimbulkan tuntutan berdasarkan perbuatan melawan hukum (Pasal1365 KUHPerdata) dapat menimbulkan pengambilan tindakan dibidang hukum pidana. Pertanggungjawaban Notaris terutama terletak dibidang hukum privat. ${ }^{14}$

Menurut Shidarta menjelaskan bahwa secara umum prinsip-prinsip tanggung jawab dalam hukum dapat dibedakan sebagai berikut: ${ }^{15}$

1. Prinsip tanggung jawab berdasarkan unsur kesalahan

13 Rahmad Hendra, Tanggungjawab Notaris Terhadap Akta Otentik yang Penghadapnya Mempergunakan Identitas Palsu di Kota Pekanbaru, Jurnal Ilmu Hukum Volume 3 No. 1, hlm. 9.

14 Wawancara dengan AGUS GIHARNO, SHLM. Panitera Muda Perdata Pengadilan Negeri Pekalongan pada tanggal 4 Agustus 2017

15 Shidarta, Op.Cit., hlm. 73-79
Prinsip tanggung jawab berdasarkan unsur kesalahan (fault liability atau liabilitybased on fault) adalah prinsip yang cukup umum berlaku dalam hukum pidana dan perdata. Dalam KUH Perdata, khususnya pasal 1365, 1366, dan 1367, prinsip ini dipegang secara teguh. Prinsip ini menyatakan, seseorang baru dapat dimintakan pertanggungjawabannya secara hukum jika ada unsur kesalahan yang dilakukannya.

Pasal 1365 KUH Perdata yang lazim dikenal sebagai pasal tentang perbuatan melawan hukum, mengharuskan terpenuhinya empat unsur pokok, yaitu:

a. adanya perbuatan;

b. adanya unsur kesalahan;

c. adanya kerugian yang diderita;

b. adanya hubungan kausalitas antara kesalahan dan kerugian.

Yang dimaksud kesalahan adalah unsur yang bertentangan dengan hukum.Pengertian hukum tidak hanya bertentangan dengan undang-undang tetapi juga kepatutan dan kesusilaan dalam masyarakat.

Tanggung jawab atas perbuatan melawan hukum dapat disengaja dan tidak disengaja atau karena lalai. Hal tersebut diatur dalam pasal 1366 KUHPerdata, sebagai berikut : "Setiap orang bertanggung jawab tidak saja untuk kerugian yang disebabkan karena perbuatannya, tetapi juga untuk kerugian yang disebabkan karena kelalaian atau kurang hatihatinya".

Tanggung jawab atas perbuatan melawan hukum diatas merupakan tanggung jawab perbuatan melawan hukum secara langsung, dikenal juga dikenal perbuatan melawan hukum secara tidak langsung menurut Pasal 1367 ayat (1) KUHPerdata : Seseorang tidak saja bertanggung jawab untuk kerugian yang disebabkan karena perbuatannya sendiri, tetapi juga untuk kerugian yang disebabkan karena perbuatan orang-orang yang menjadi tanggungannya atau disebabkan oleh barangbarang yang berada di bawah pengawasannya. Tanggung jawab tersebut berakhir, jika seseorang itu membuktikan bahwa dia tidak dapat mencegah perbuatan untuk mana 
mereka seharusnya bertanggung jawab (Pasal 136 ayat (5) KUHPerdata).

2. Prinsip praduga untuk selalu bertanggung jawab

Prinsip ini menyatakan bahwa tergugat selalu dianggap bertanggung jawab (presumption of liability principle), sampai ia dapat membuktikan bahwa ia tidak bersalah. Menurut E. Suherman sebagaimana "dianggap" pada prinsip "presumption of liability" adalah penting, karena ada kemungkinan tergugat membebaskan diri dari tanggung jawab, yaitu dalam hal ia dapat membuktikan bahwa ia telah "mengambil" semua tindakan yang diperlukan untuk menghindarkan terjadinya kerugian.

Dalam prinsip ini, beban pembuktiannya ada pada si tergugat. Dalam hal ini tampak beban pembuktian terbalik (omkering van bewijslast). Hal ini tentu bertentangan dengan asas hukum praduga tidak bersalah (presumption of innocence). Namun jika diterapkan dalam kasus konsumen akan tampak asas demikian cukup relevan. Jika digunakan teori ini, maka yang berkewajiban untuk membuktikan kesalahan itu ada pada pihak pelaku usaha yang digugat. Tergugat harus menghadirkan bukti-bukti bahwa dirinya tidak bersalah. Tentu saja konsumen tidak dapat sekehendak hati mengajukan gugatan. Posisi konsumen sebagai penggugat selalu terbuka untuk digugat balik oleh pelaku usaha, jika ia gagal menunjukkan kesalahan tergugat.

3. Prinsip praduga untuk tidak selalu bertanggung jawab

Prinsip ini adalah kebalikan dari prinsip yang kedua, prinsip praduga untuk tidak selalu bertanggung jawab hanya dikenal dalam lingkup transaksi konsumen yang sangat terbatas. Contoh dari penerapan prinsip ini adalah pada hukum pengangkutan. Kehilangan atau kerusakan pada bagasi kabin atau bagasi tangan, yang biasanya dibawa dan diawasi oleh penumpang (konsumen) adalah tanggung jawab dari penumpang. Dalam hal ini pengangkut (pelaku usaha) tidak dapat dimintakan pertanggungjawabannya. Pihak yang dibebankan untuk membuktikan kesalahan itu ada pada konsumen.
4. Prinsip tanggung jawab mutlak

Prinsip tanggung jawab mutlak (strict liability) sering diidentikkan dengan prinsip tanggung jawab absolut (absolute liability). Kendati demikian ada pula para ahli yang membedakan kedua terminologi di atas. Ada pendapat yang menyatakan, strict liability adalah prinsip tanggung jawab yang menetapkan kesalahan tidak sebagai faktor yang menentukan. Namun ada pengecualian pengecualian yang memungkinkan untuk dibebaskan dari tanggung jawab, misalnya pada keadaan force majeure. Sebaliknya absolute liability adalah prinsip tanggung jawab tanpa kesalahan dan tidak ada pengecualiannya.

Menurut E. Suherman, strict liability disamakan dengan absolute liability, dalam prinsip ini tidak ada kemungkinan untuk membebaskan diri dari tanggung jawab, kecuali apabila kerugian yang timbul karena kesalahan pihak yang dirugikan sendiri. Tanggung jawab adalah mutlak.

5. Prinsip tanggung jawab dengan pembatasan.

Prinsip tanggung jawab dengan pembatasan (limitation of liability principle) ini sangat disenangi oleh pelaku usaha untuk dicantumkan sebagai klausula eksonerasi dalam perjanjian standar yang dibuatnya.

Konsep pertanggungjawaban ini apabila dikaitkan dengan profesi Notaris, maka Notaris dapat dipertanggung jawabkan atas kesalahan dan kelalaiannya dalam pelaksanaan tugas dan jabatannya. Notaris tidak bertanggung jawab atas isi akta yang dibuat di hadapannya, melainkan Notaris hanya bertanggung jawab terhadap bentuk formal akta otentik sebagaimana yang ditetapkan oleh Undang-undang.

Apabila seseorang dirugikan karena perbuatan seseorang lain, sedang diantara mereka itu tidak terdapat sesuatu perjanjian (hubungan hukum perjanjian), maka berdasarkan undang-undang juga timbul atau terjadi hubungan hukum antara orang tersebut yang menimbulkan kerugian itu.16 Hal tersebut diatur dalam pasal 1365 KUHPerdata,

16 AZ Nasution, 2002, Hukum Perlindungan Konsumen, cet .2, Diapit Media, Jakarta, hlm.77. 
sebagai berikut : Tiap perbuatan melanggar hukum yang membawa kerugian pada orang lain, mewajibkan orang yang karena salahnya menerbitkan kerugian itu, mengganti kerugian tersebut.

Menurut pasal 1365 KUHPerdata, maka yang dimaksud dengan perbuatan melanggar hukum adalah perbuatan yang melawan hukum yang dilakukan oleh seseorang yang karena salahnya telah menimbulkan kerugian bagi orang lain. Dalam ilmu hukum dikenal 3 (tiga) kategori dari perbuatan melawan hukum, yaitu sebagai berikut:

1. Perbuatan melawan hukum karena kesengajaan

2. Perbuatan melawan hukum tanpa kesalahan (tanpa unsur kesengajaan maupun kelalaian)

3. Perbuatan melawan hukum karena kelalaian.17

Pada prinsipnya wujud pertanggungjawaban Notaris terhadap akta yang dibatalkan oleh pengadilan adalah :

1. Pertanggungjawaban secara administratif Apabila seorang Notaris terbukti melakukan pelanggaran pasal 85 Undang-undang Nomor 30 Tahun 2004 yang mengatur mengenai kewajiban dan larangan bagi Notaris dalam menjalankan jabatannya.

Pasal 85 UUJN menerangkan apabila Notaris melanggar ketentuan sebagaimana dimaksud dalam Pasal 7, Pasal 16 ayat (1), huruf a s/d k, Pasal 17, Pasal 20, Pasal 27, Pasal 32, Pasal 37, Pasal 54, pasal 54, Pasal 58, Pasal 59, dan atau Pasal 63 dapat dikenakan sanksi berupa sanksi Pertanggungjawaban Notaris. administratif sesuai dengan berat ringannya pelanggaran yang dilakukan.

Dalam Pasal 85 Undang-undang Nomor 30 Tahun 2004 menyatakan apabila Notaris melanggar ketentuan Pasal tersebut diatas maka dapat dikenakan sanksi berupa :
a. Teguran lisan;
b. Teguran tertulis;
c. Pemberhentian sementara;
d. Pemberhentian dengan hormat;
e. Pemberhentian dengan tidak hormat.

2. Pertanggungjawaban menurut Hukum Perdata

17 Munir Fuady, 2002, Perbuatan Melawan Hukum, cet.1, Citra Aditya Bakti, Bandung, hlm.3.
Menurut Pasal 1365 KUHPerdata, "Tiap perbuatan melanggar hukum, yang membawa kerugian kepada seorang lain, mewajibkan orang yang karena salahnya menerbitkan kerugian itu, mengganti kerugian". Pasal 84 UU Nomor 30 Tahun 2004 mengatur mengenai halhal yang berkaitan dengan akta, apabila dilanggar oleh Notaris akan berakibat suatu akta hanya mempunyai kekuatan pembuktian sebagai akta di bawah tangan atau suatu akta menjadi batal demi hukum. Hal ini dapat menjadi alasan bagi pihak yang menderita kerugian untuk menuntut penggantian biaya, ganti rugi dan bunga kepada Notaris.

Berdasarkan ketentuan tersebut diatas maka Notaris yang karena kelalaiannya dalam membuat akta telah merugikan orang lain maka apabila di pengadilan terbukti bersalah Notaris tersebut dapat dihukum untuk mengganti kerugian, bunga, biaya atau memulihkan keadaan hukum seseorang karena perbuatannya, kesalahannya telah menimbulkan kerugian yang tidak dikehendaki.

Diluar dari akta terdegradasi nilai pembuktiannya sebagai akta di bawah tangan, tidak ada sansi perdata yang lainnya, artinya UUJN sendiri telah menentukan hanya akta Notaris yang terbukti terdegradasi nilai pemnbuktiannya sebagai akta dibawah tangan yang dapat dijatuhi sanksi perdata. untuk akta notaris yang dibatalkan, Akta Notaris yang dapat dibatalkan, Akta Notaris batal demi hukum, Akta Notaris tidak mempunyai kekuatan hukum mengikat dan Akta Notaris tidak sah tidak ada sanksi apapun untuk Notaris.

3. Pertanggungjawaban menurut Hukum Pidana

Apabila dalam pemeriksaan pengadilan Notaris tersebut terbukti bersalah maka bentuk pertanggungjawaban Notaris secara Hukum Pidana dapat berupa:

a. Hukuman Pokok:
1) Penjara
2) Kurungan
3) Denda

b. Hukuman tambahan

1) Pencabutan beberapa hak tertentu

2) Perampasan beberapa benda tertentu yang menjadi barang bukti 


\section{PENUTUP}

\section{Kesimpulan}

Dari uraian di atas terkait penulisan dengan judul"Akibat Hukum Akta Otentik Yang Terdegradasi Menjadi Akta Dibawah Tangan" dapat penulis simpulkan sebagai berikut :

1. Akta otentik dapat terdegradasi menjadi akta di bawah tangan ketika syarat-syarat dalam akta otentik tersebut tidak terpenuhi, baik syarat materiil ataupun syarat formilnya yanga mana yang mempunyai kewenangan untuk menilai hal tersebut adalah pengadilan.

2. Apa akibat hukum akta otentik yang terdegredasi menjadi akta dibawah tangan tidak mempunyai kekiatan hukum sebagai akta otentik, hanya menjadi kata di bawah tangan yang tidak mempunyai kekuatan hukum mengikat hal ini berdasarkan KUHperdata pasal 1869 serta dapat dilihat pada UU No. 2 Tahun 2014 jo. UU No. 30 Tahun 2004 Pasal 16 angka (9), Pasal 41, Pasal 44, Pasal 48 ayat (3) Pasal 49 ayat (4), Pasal 50 ayat (5), Pasal 51 ayat (4).

3. Tanggung jawab Notaris jika akta otentik yang dibuatnya menjadi akta dibawah tangan, Notaris dapat di mintai pertanggungjawaban yaitu ;

a. Pertanggungjawaban secara administratif Apabila seorang Notaris terbukti melakukan pelanggaran pasal 85 Undang-undang Nomor 30 Tahun 2004 yang mengatur mengenai kewajiban dan larangan bagi Notaris dalam menjalankan jabatannya.

b. Pertanggungjawaban menurut Hukum Perdata hal ini sebagaimana Pasal 1365 KUHPerdata, serta dapat dilihat pada UU No. 2 Tahun 2014 jo. UU No. 30 Tahun 2004 Pasal 16 angka (9), Pasal 41, Pasal 44, Pasal 48 ayat (3) Pasal 49 ayat (4), Pasal 50 ayat (5), Pasal 51 ayat (4).

c. Pertanggungjawaban menurut hukum pidana apabila Notaris sengaja memalsukan akta otentik atau sengaja memasukan keterangan tidak benar dalam akta otentik yang di buatnya

\section{Saran}

1. Untuk para penguna jasa Notaris supaya memberi keterangan yang benar dalam memberi keterangan kepada Notaris dalam akta otentik.

2. Untuk Notaris dalam pembuatan akta harus berdasarkan keterangan yang benar serta sesuai dengan peraturan perundangan yang berlaku.

\section{DAFTAR PUSTAKA}

A.A.Andi Prajidno,2010,Apa dan Siapa Notaris di Indonesia ?, Cet. Pertama,Putra Media Nusantara,Surabaya.

AZ Nasution, 2002, Hukum Perlindungan Konsumen, cet .2, Diapit Media, Jakarta.

Komar Andasasmita, 1983, Notaris Selayang Pandang, Cet.kedua,Alumni, Bandung.

Munir Fuady, 2002, Perbuatan Melawan Hukum, cet.1, Citra Aditya Bakti, Bandung.

R.Subekti dan R.Tjitrosudibio,1995, Kitab Undangundang Hukum Perdata cet.27..Pradnya Paramita,Jakarta.

Rahmad Hendra, Tanggungjawab Notaris Terhadap Akta Otentik yang Penghadapnya Mempergunakan Identitas Palsu di Kota Pekanbaru, Jurnal Ilmu Hukum Volume 3 No. 1.

Sudikno Mertokusumo,2006, Hukum Acara perdata Indonesia, Liberty, Yogyakarta

R.Subekti,2001,Hukum Pembuktian,Pradinya Paramita Jakarta.

Taufik Makarao,2004,Pokok-Pokok Hukum Acara Perdata, Rinaka Cipta, Jakarta,h.100.

Teguh Samudra,2004,Hukum Pembuktian dalam Acara Perdata, edisi pertama, Alumni , Bandung.

Wawan Tunggal Alam,2001,Hukum Bicara Kasuskasus dalam Kehidupan Sehari-hari,Milenia Populer, Jakarta. 